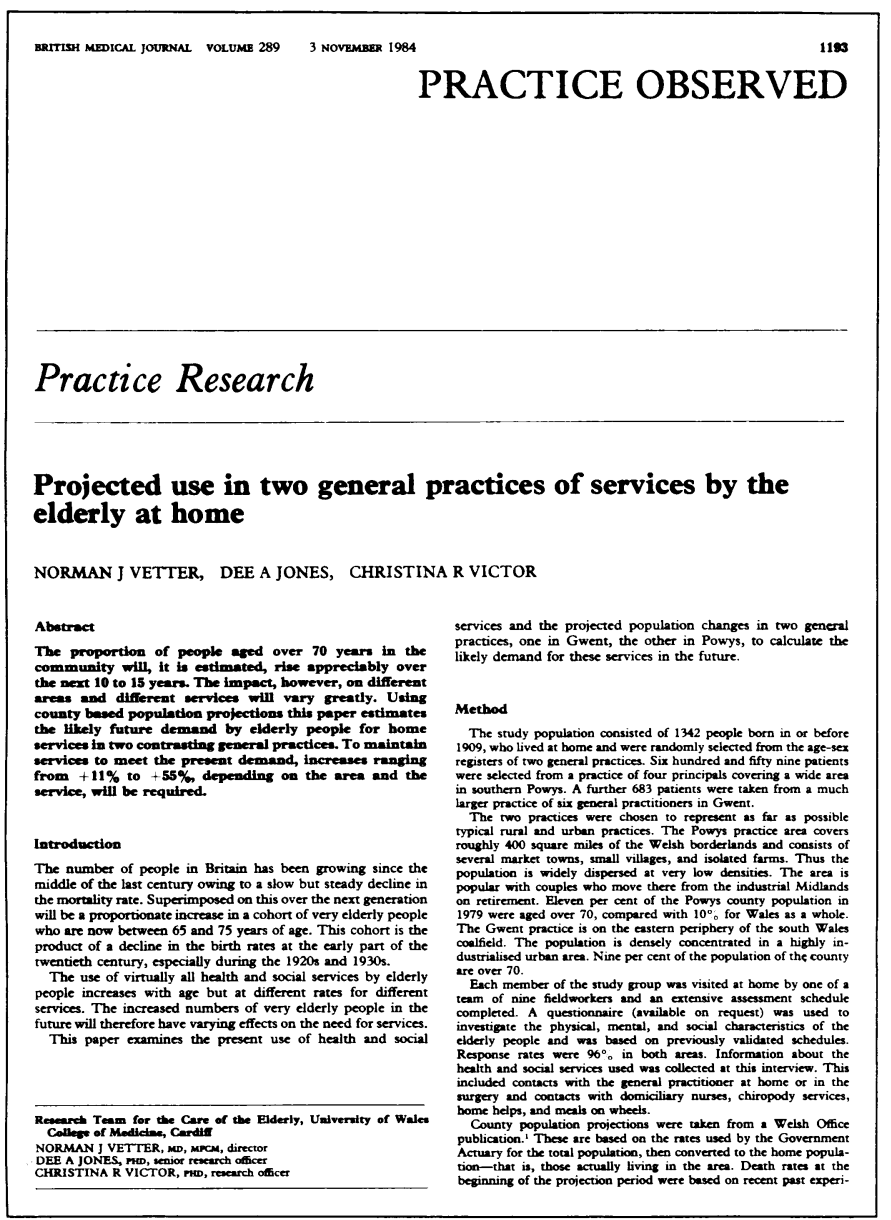
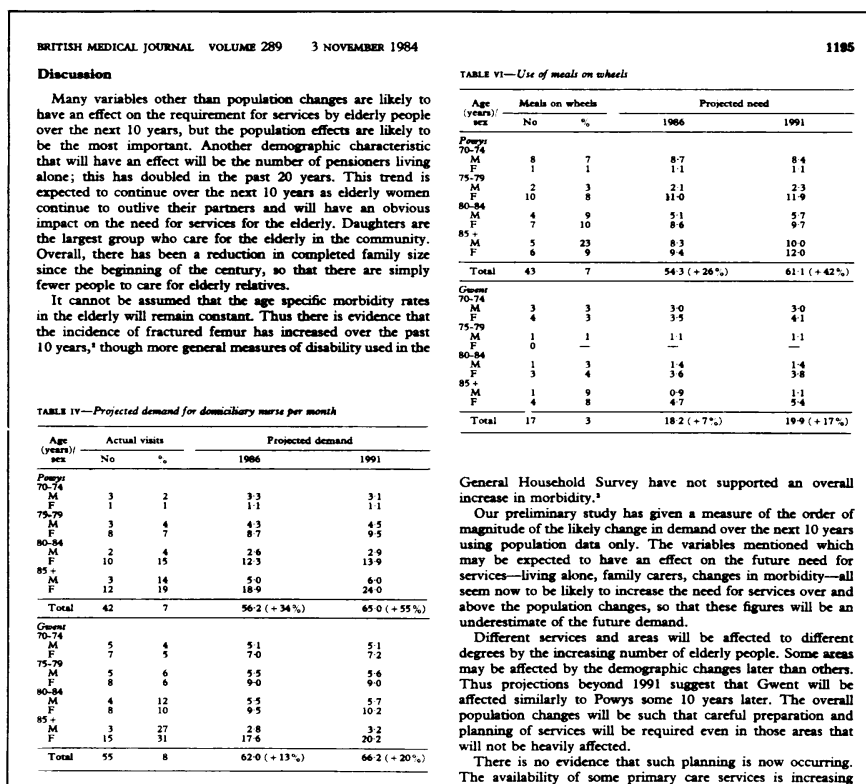

General Houschold Survey have not supported an overall

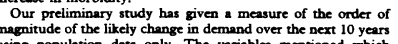
may be expected to have an effect on the futurec deed for
services-living alone, family caress, changes in morbididy - all

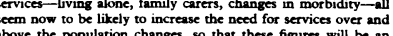

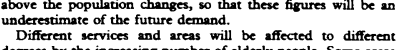

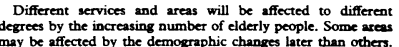

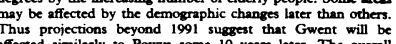
population changes will be such that careful preparation and
planning of services will be required even in those areas that There is bo vevidenceth that such planning is now occurring.
The availability of some primary care services is increasing but this is not ruve of all such services. Thus over the past five
years in wales there has been 2 decline of $14 \%$ in the visists

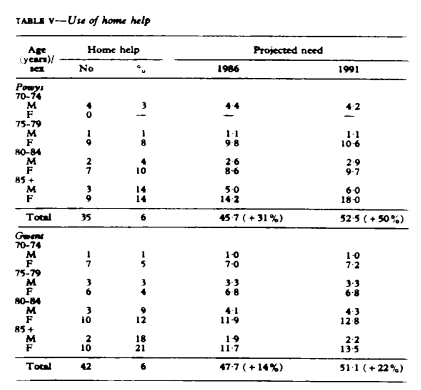

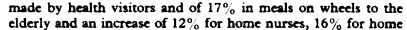

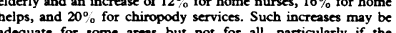
adequate for some areas but not for all, particularty if the
provision for residential care remains static, as it has done for
some years.

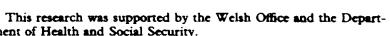

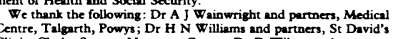

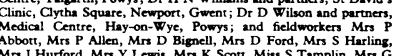

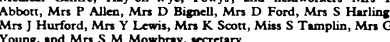
References

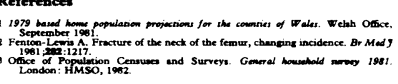

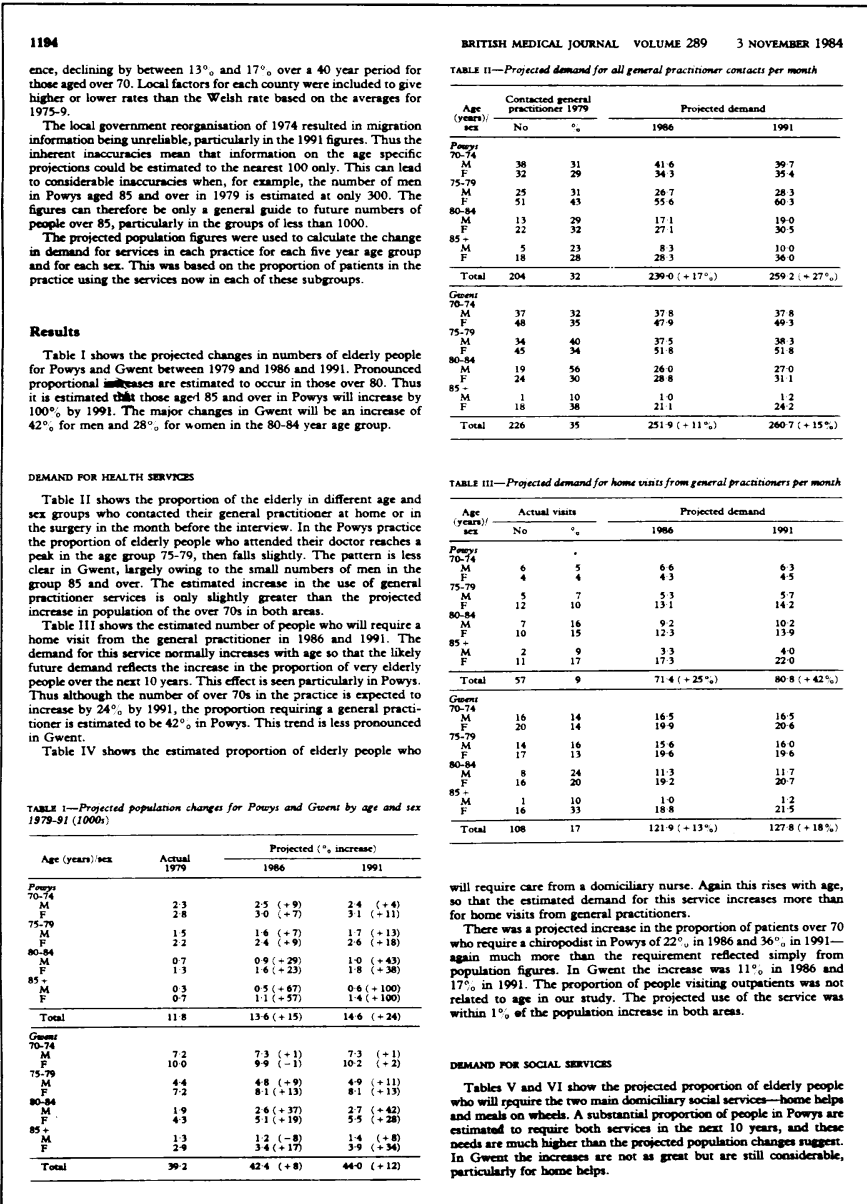

1196 Comparison of prescription costs within a group practice L BaUmGard, P Frank, J A REes, K SHeArer

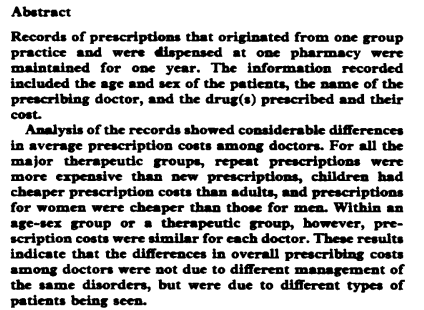
Introduction

One aspect of clinical freedom is the right to prescribe whatever
drug a doctor considers to be appropriate for the treamente


scribing costs of individual doctors, with the result that some
docrors are labelled as " hight cost prescribers." Litrle resecarce

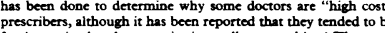

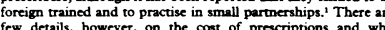
prescribing costs may vary among doctors.
In one group practice of five doctors one parterer was con-

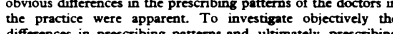

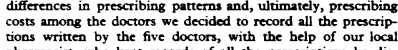

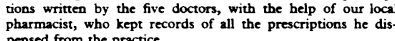
Mectood

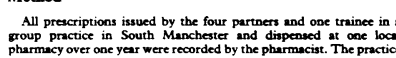

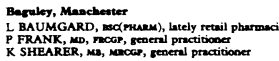

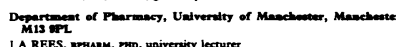

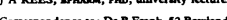

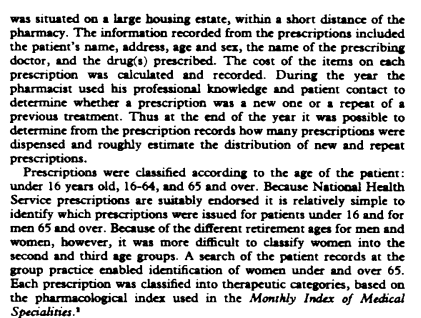

Resulas

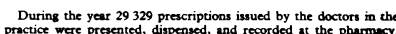

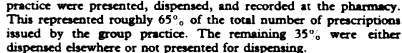

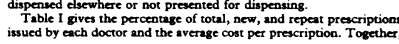

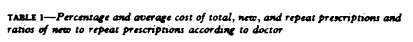

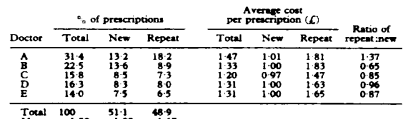

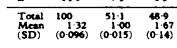

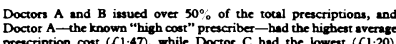

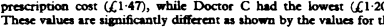

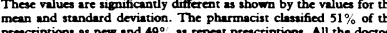



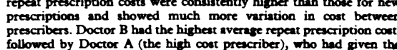

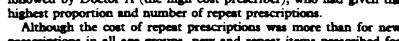

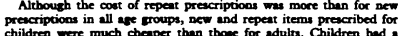

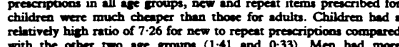

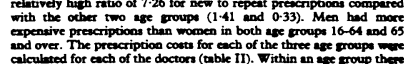

w్ 


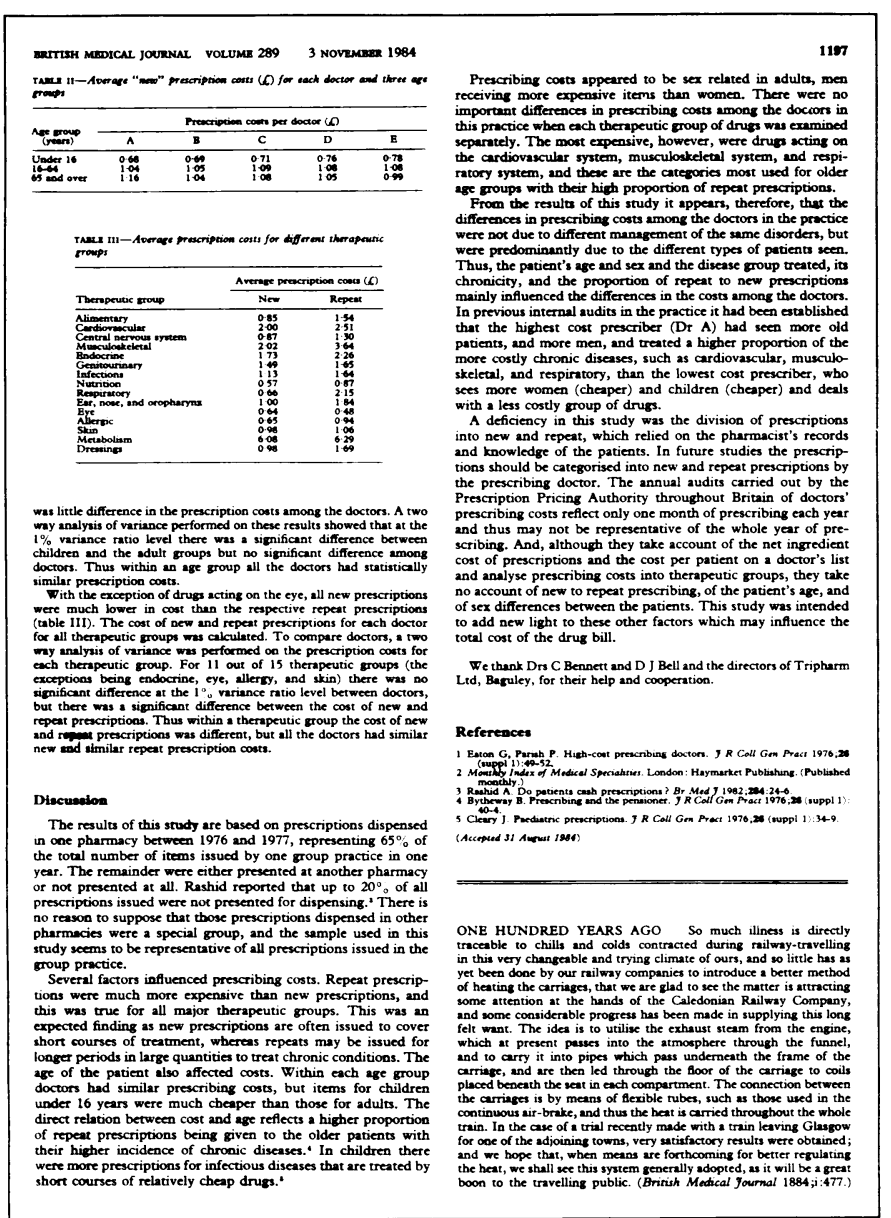

119

\section{Research in General Practice}

\section{Sources of advice}

N C H STOTT, R C FRASER, D C MORRELI

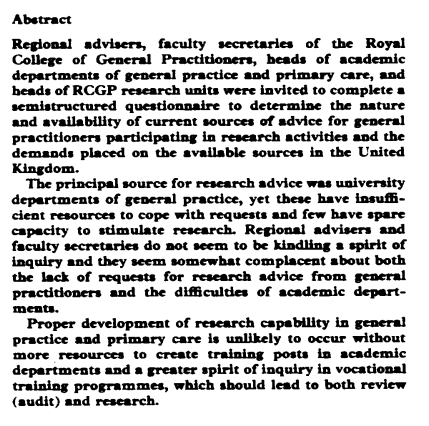

Introduction
Nethough general practionerers have been responsible for many

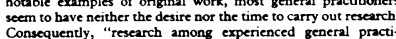


is still, alas, distinctly unusual." Inded, it has been estimated
that in a year only one general practioner in 300 will publish a Among the small minority of general practitioners who do
undertake rescarch a lack of methodological skill is too often
und 2pparent.' It is distressing to be called on to advise on
completed research project which has been so poorly designed
that the data produced cannot be usefully interereteted and the practitioners concerned have invariably expended a great deal
time and effort (and often ingenuiry). Such an experience tend

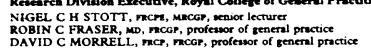

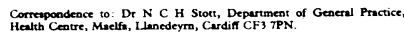

to lead to frustration and consequent disenchantment with
further participation in nersearch activities further participation in research activities.
One reason for this unsarisfactory state of aftairs is that few general practitioners have received formal training to enable
them to 2 acuuire research skills and recognise when help is prospective general practitioner researchers must be made aware ef the particular radvantages and
problems of carrying out research in the serting of genera practice." "They also require ready access to skilled advice and support, particularly at the design and analysis stages of research
projects. No formal network of support exists, although ad hoc advice and support may be avaiable from university depart-
ments, the Royal College of General Praccitioners research units, and the research division of the college.
If general practitioner researchers are to make che contribu-

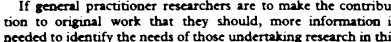
needed to identify the needs of those undertaking research in this
subiect and of the level of support services available to them. (1) To determine the nature and avalability of current
sources of advice for general practitioners perticipating in research activities.
(2) $T_{0}$ assess the demands made on available sources of

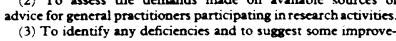

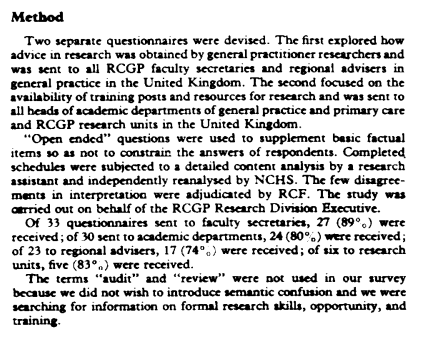
educational cuts.
The imms of the study were as follows:
(1) To determine the nature and avalability of current ments
(4) To provide a factual basis for debarec, which is central to the
future of primary health care and general practicc.

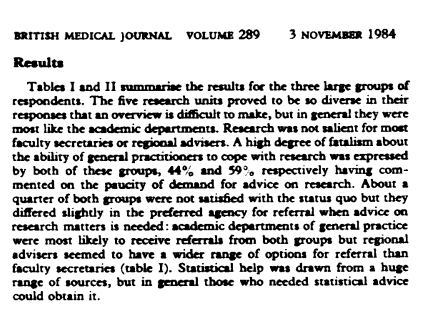

\begin{tabular}{|c|c|c|}
\hline & 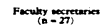 & Reconons tariver \\
\hline & $\therefore(\mathrm{n})$ & $\because$ (a) \\
\hline 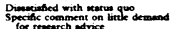 & (22) & $\begin{array}{l}5(29) \\
10.59\end{array}$ \\
\hline 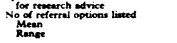 & $i_{1-17}$ & 年 \\
\hline 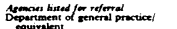 & & \\
\hline  & 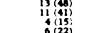 & 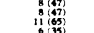 \\
\hline 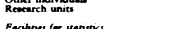 & $\xi(16)$ & 2(12) \\
\hline 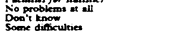 & $\begin{array}{l}14(32) \\
10(1) \\
10(3)\end{array}$ & 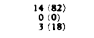 \\
\hline 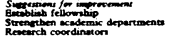 & 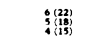 & $\stackrel{3}{3}(49)$ \\
\hline
\end{tabular}

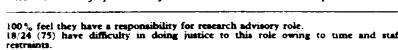

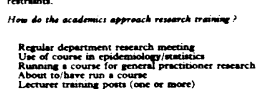

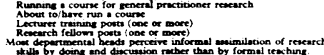

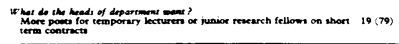

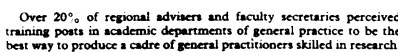

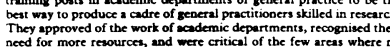

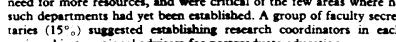

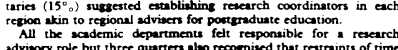

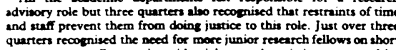

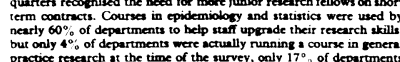

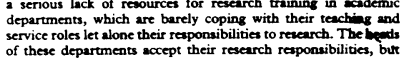
of these departments coccept their research repponsibilitices, bir
most find themselves too tied in administrative and teaching duties. There are, bowever, a few exceppions tocthis dismal picture,
and the next decade will show whecher those depertments that

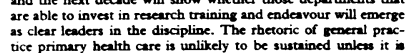

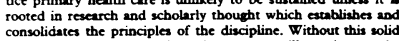
consolidates the principles of the discipline. Without this solid
foundation, general practice primary care will continue to be
manipulated bither and thither by principles and practices that manipulated bither and thither by principles and practices that
are more appropriate to specialist than to our diaccipine.
Who should be developing recearch stills ? In every discipline

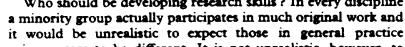

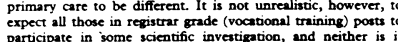

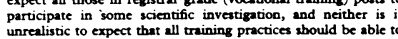

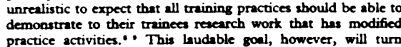

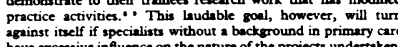
have excessive influence on the nature of the proiects undertaken
This is the Carch-22: how can we train a cadre of good researc

1200

workers to be academic leaders without overioad of the few
existing skilled people and without becoming smothered by enthusiasts from without the discipline of primary care?
In this survey several solutions were suggested. The idea that

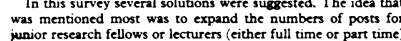
wanior research fellows or lecturers (either full time or part time)
in academic departments of general practice. This would in efferter expand the academic grades and produce people who would
prepering to become academis, regional addives, course
organisers, or individual researchers. The cost if such poses organisers, or individual researchers. The cost of such pos
might be relatively low if they were established for onc to thre might be relatively low if they were established for one to the
years. During that time research skills could be develeoped and
these doctors would be capable of pursuing independent resear these doctors would be capable of pursuing independent research
in the furure as well as providing an advisory service for colleagues.
Could academic departments of general practice cope with
more junior staff? The answers from the heads of department more junior staff? The answers from the heads of department
were not uniform about the problems this would cause or solve,
but in igeneral they were positive about the idea, provided that were not unform about the problems this would cause or solve,
but in general they werc positive about che idea, provided thai
the balance between teaching and research could be met and

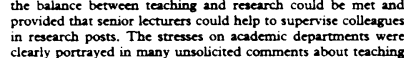
clearly portrayed in many unsolicited comments about teaching
loads and administrative responsibilities. Another more costly suggession (originally put forward by
RCF) and mentioned by $15 \%$ of faculty secretaries, was the

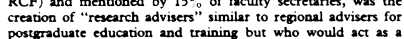

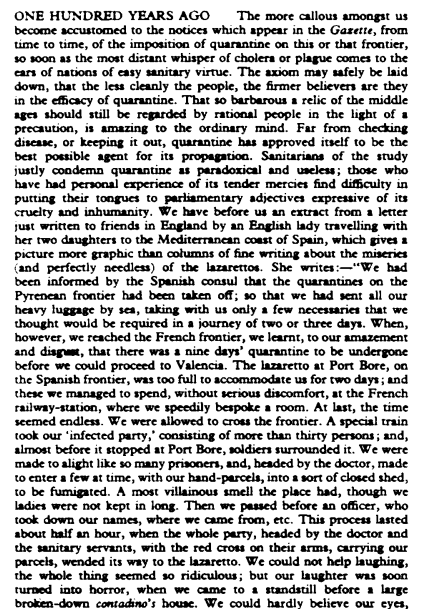

BRTIISH MPDICAL JOURNAL VOLUME $289 \quad 3$ NOVEMBER 1984 resource for research. Such a post hes no parallel in other
disciplines and the relationship berween such people and the academic departments would have to be clarified if dissociation
between rescerch and postgraduate training is not to be perpetuated.
We hope that this survey will kindle discussion and serious tiscipline and the vocational training we organise. We are grateful to all those senior doctors who compleeted our
questionnaire end to Jenny Berbolomew for her help in the preliminary

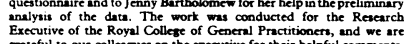

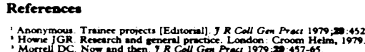

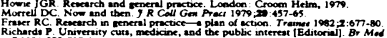

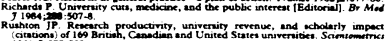

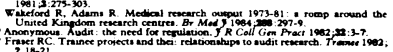
Accepted 19 ron 1980

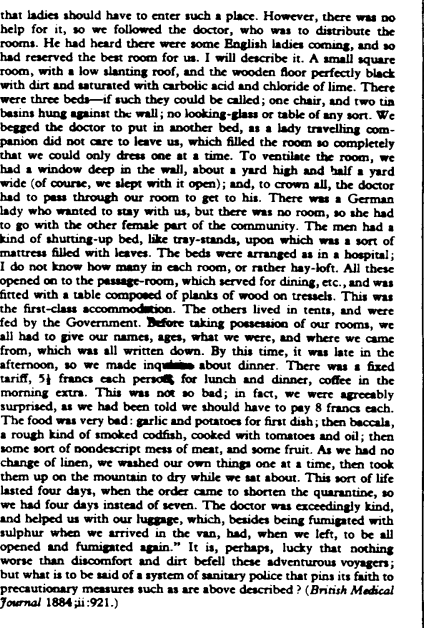

